\title{
THE EFFECT OF THE STRUCTURE OF MANAGEMENT AND EMPLOYEES ON GUEST'S SATISFACTION OF RESTAURANT PRODUCTS AND SERVICES
}

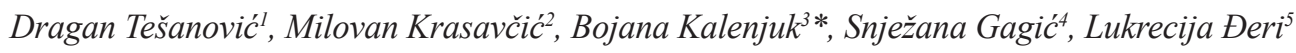
*Corresponding author E-mail: bojana.kalenjuk@dgt.uns.ac.rs

A R T I C L E I N F O
Review Article
Received: 03 July 2018
Accepted: 04 September 2018
doi:10.5937/ekoPolj1803193T
UDC [005+331.108.23]:640.43

Keywords:

structure of employees, satisfaction, quality, restaurant industry, hospitality

JEL: D11, M12, I21, P46

\begin{abstract}
A B S T R A C T
The purpose of this research is to define the effects of the structure of management and employees to the guest's satisfaction in terms of quality of restaurant products and services. The methodology used for this research has been the polling of 600 guests in 30 restaurants in Belgrade during 2015. The process of measuring satisfaction was performed by monitoring the attitudes and perceptions of users in terms of quality of products and services, which marks food quality, service quality, and ambience quality and price/quality ratio. The research of educational and age structure, as well as the number of supporting staff and other workers, has been conducted. Correlation and regression analysis were performed with the aim of defining the effect of the educational structure of employees to guest's satisfaction. The results show that restaurant managers should pay special attention to educational levels of employees through regular and permanent education, as they influence the guest's satisfaction.
\end{abstract}

(C) 2018 EA. All rights reserved.

1 Dragan Tešanović, PhD, Full Professor, Faculty of Sciences, University of Novi Sad, Trg Dositeja Obradovića 3, Novi Sad, Serbia; Phone: +381 21450 105; E-mail: dragan. tesanovic@dgt.uns.ac.rs; https://orcid.org/0000-0003-1675-5654

2 Milovan Krasavčić, PhD, Professor, The College of Hotel Management, Kneza Višeslava 70, Belgrade, Serbia; Phone: +381 11 2547255; E-mail: milovan.krasavcic@gmail.com; https://orcid.org/0000-0001-7041-0054

3 Bojana Kalenjuk, PhD, Assistant Professor, Faculty of Sciences, University of Novi Sad, Trg Dositeja Obradovića 3, Novi Sad, Serbia; Phone: +381 21450 602; E-mail: bojana. kalenjuk@dgt.uns.ac.rs; https://orcid.org/0000-0003-0661-5359

4 Snježana Gagić, PhD, Assistant Professor, College of Professional Studies in Management and Business Communication, Mitropolita Stratimirovića 110, Sr. Karlovci, Serbia; Phone: +381 21882 892; E-mail: gagicsnjeza@yahoo.com; https://orcid.org/0000-0001-8940-552X

5 Lukrecija Đeri, PhD, Associate Professor, Faculty of Sciences, University of Novi Sad, Trg Dositeja Obradovića 3, Novi Sad, Serbia; Phone: +381 21450 105; E-mail: lukrecija. djeri@dgt.uns.ac.rs; https://orcid.org/0000-0001-8696-764X

http://ea.bg.ac.rs 


\section{Introduction}

Customer satisfaction with product and service quality is the basis of stable business and attracting guests. Guests will choose restaurants that meet their expectations and requirements, while the management of the restaurant that does not consider the wishes and requirements of guests will experience a drop in turnover as a result of directing dissatisfied guests towards competing for restaurants (Caruana et al., 2000; Sureshchandar et al., 2002; Seth, Deshmukh, Vrat, 2005; Marinković et al., 2013). For this reason, quality of service and customer satisfaction have become the focus of many researchers because it is found that both factors have an impact on better business and their behaviour (Syed et al., 2011).

Modern literature in the service filed pays great attention to customer satisfaction with products and services, indicating that in order to achieve a high level of customer satisfaction, organizations need to identify, measure and manage the inner elements that produce it (Yuksel, Yuksel, 2002; Wang, 2011).

Previous research (Namkung, Jang, 2007; Kim et al., 2009), have shown that elements of quality according to which customer satisfaction is measured in this study as well (food quality, service quality, environment quality and quality/price ratio) have a significant impact on the operation of the hospitality facility which is closely linked to the qualification structure of employees (Brooks, 2000; Sulek, Hensley, 2004; Han, Ryu, 2009), which confirms that the development of measures for quality improvement is a basic precondition for a successful business and survival on restaurant market (Blesic et al., 2010).

Taking into account heterogeneity of services in the restaurant industry and personal dimension of their realization, it is extremely difficult to reach total customer satisfaction. Measurement of satisfaction enables finding out what is the most important for users of services, how they perceive the specific facility and, finally and most importantly, setting priorities for improvement in order to increase customer satisfaction and thereby profitability of a facility. Many studies have shown that profitability has a direct impact on customer satisfaction (Luo, Homburg, 2007).

The challenges of the modern world, dominated by knowledge and high technology, have imposed that education, knowledge and innovation of employees became key drivers for change management and gaining a competitive advantage (Pološki et al., 2007; Suh et al., 2012), which contributed to researching the significance of education level of employees for the quality of hospitality products and services (Baum, Nickson, 1998; Stewart, 2001; Connolly, McGing, 2006).

By applying the appropriate model, research results will indicate the level of influence and importance the structure of management and staff has on the guest satisfaction with the quality of products and services. The paper will examine the guest satisfaction by assessment of environment, inner atmosphere, quality of service, food, drinks and prices, and then it will show the staff structure in restaurants through the analysis of qualification of all 
managerial positions (restaurant manager, banquet manager, kitchen manager) and a number of cooks, waiters, assistant workers, other workers and the total number of employees in Belgrade restaurants. The research was conducted from March till October 2015.

\section{Literature review}

\section{Customer satisfaction}

Customer satisfaction is considered a key factor in the assessment of organizational performances. Companies try to increase customer satisfaction in order to ensure their competitive advantage, assuming that the implementation of the evaluation of customers gives better organizational results (Martíneztur et al., 2011).

Bolton and Drew (1991) believe that customer satisfaction is a sign of the quality of services provided by the facility.

According to Stevens et al. (1995), the restaurant consumers determine which restaurants meet their quality and value standards and restaurateurs that do not recognize this will experience a decline in consumption, which suggests that the achievement of customer satisfaction and loyalty is realized through the provision of exceptional value (Weiss et al., 2005).

Consumers who are very dissatisfied generally do not complain but leave restaurants, do not use their products and services anymore, in a word they boycott it. In some cases, customers may be satisfied, but do not carry out the re-order. The true economic benefit is achieved through customer satisfaction, which is manifested by their loyalty (Fick, Ritchie, 1991).

A satisfied customer makes recommendations to other potential customers, returns to perform a repeat purchase, and sometimes she/he is ready to pay extra for a product or service of reliable company (Knuston et al., 1992).

\section{The role of education and knowledge of employees in the hospitality industry}

For an individual to meet requirements of a particular job, it is necessary to possess adequate qualifications, experience and functional ability (mental and physical capacity), as hospitality workers are in constant and direct contact with people of different mentalities and habits. Significance of education in the hospitality industry has been dealt by authors in different ways, Durrani and Rajagopal (2016) examined what impact on selection of employees has an education level of the management, however it is important to indicate the three main reasons why the education and skills of workers are important for a success of the hospitality facility:

1. In today's scientific environment, only educated personnel can bring a competitive advantage to the organization (Stewart, 2001), there are many examples of companies that successfully operate and whose employees are not well educated and trained, but it cannot be the reason why young people with university degrees should not be employed to improve hospitality businesses, strengthen business of hospitality companies and make them more competitive (Connolly, McGing, 2006). 
2. Employees in the hospitality industry are vital for hospitality organization because the ability to provide products and services depends on their enthusiasm.

3. Only a small number of jobs can be performed without qualification because jobs require a specific understanding of hospitality services, guests are representatives of different cultures on which employees must be informed, they should speak different languages, have perfect communication skills, etc. (Baum, Nickson, 1998).

\section{Factors that influence the consumer satisfaction in restaurants}

Quality is one of the most commonly used words that are related to food and food service, as well as other products and services that interact with consumers.

Food quality is generally accepted as the main factor affecting customer satisfaction. Sulek and Hensley (2004) suggest that when comparing all aspects of quality, besides ambience, quality of services is also one of the most important parameters (Baker et al., 2002; Kim, Moreo, Yeh, 2004), and the quality of food is the most important element of customer satisfaction. Namkung and Jang (2007) tested the impact of food quality on customer satisfaction and behavioural intentions and found a positive relationship between the attributes that make the quality of the food (e.g. presentation of food, offer types, healthy options, taste, freshness and temperature of food) and customer satisfaction and behavioural intentions. Prestige of local products and national identity also have a positive and statistically significant impact on the assessment of food products (Šapić, Furtula \& Durkalić, 2018).

Previous studies have shown that the atmosphere is a key factor in attracting and satisfying customers and increasing financial performances through the market share in the hospitality industry (Heide, Gronhaug, 2009; Zemke, Shoemaker, 2008; Liu, Jang, 2009). The ambience and the scent can influence the consumers' mood, emotion, or a subjective feeling (Chebat et al., 2009). The results showed that the scent of lavender, but not of a lemon, statistically significantly affects the time of guests stay and the amount of spent money (Gueguen, Petr, 2006). Research on effects of olfactory sensations conducted by Zemke and Shoemaker (2007) consisted of measuring the frequency of social interaction; it is proved that ambient scents have a positive correlation with the frequency of social interactions within the facility.

In addition to the food, service, ambience and atmosphere, it is considered that the price can be another factor that affects the customer satisfaction and behavioural intentions (Andaleeb, Conway, 2006). The perceived fairness of prices represents a relationship with the satisfaction and loyalty of clients, which from the standpoint of the consumer price unfairness can lead to a direct negative attitudes and behaviours, such as dissatisfaction, complaints and changes of the restaurant (Xia et al., 2004). 


\section{Methodology}

\section{Place of research}

The survey was conducted on the territory of the City of Belgrade, the capital of the Republic of Serbia, 30 restaurants were selected by a free sample during 2015. In the research and presented results, restaurants are numbered from 1 to 30 .

\section{Collecting data on consumer satisfaction}

For researching consumer satisfaction with the quality of products and services 600 guests were interviewed using the modified Soriano model (Soriano, 2002). This model assesses the quality of food, service, ambience and price/quality ratio. The model included another element of quality - the atmosphere in restaurants. Evaluation of the studied elements was done using the numerical and verbal scale ranging from 1 to 10, as shown in Table 1 .

Table 1. Numerical and verbal scale for evaluation of customer satisfaction with quality of restaurant products and services

\begin{tabular}{|c|c|c|c|c|c|}
\hline Mark & Ambience & $\begin{array}{c}\text { Internal } \\
\text { atmosphere }\end{array}$ & Service quality & $\begin{array}{c}\text { Food and } \\
\text { beverage quality }\end{array}$ & Prices \\
\hline 1 & Bad & Bad & Bad & Bad & Very high \\
\hline 2 & Moderately bad & Moderately bad & Moderately bad & Moderately bad & High \\
\hline 3 & Tolerable & Tolerable & Tolerable & Tolerable & Modestly high \\
\hline 4 & $\begin{array}{c}\text { Relatively } \\
\text { satisfactory }\end{array}$ & $\begin{array}{c}\text { Relatively } \\
\text { satisfactory }\end{array}$ & $\begin{array}{c}\text { Relatively } \\
\text { satisfactory }\end{array}$ & $\begin{array}{c}\text { Relatively } \\
\text { satisfactory }\end{array}$ & Above average \\
\hline 5 & Satisfactory & Satisfactory & Satisfactory & Satisfactory & Above average \\
\hline 6 & $\begin{array}{c}\text { Below the } \\
\text { expected }\end{array}$ & $\begin{array}{c}\text { Below the } \\
\text { expected }\end{array}$ & $\begin{array}{c}\text { Below the } \\
\text { expected }\end{array}$ & $\begin{array}{c}\text { Below the } \\
\text { expected }\end{array}$ & $\begin{array}{c}\text { Relatively as } \\
\text { expected }\end{array}$ \\
\hline 7 & $\begin{array}{c}\text { Relatively as } \\
\text { expected }\end{array}$ & $\begin{array}{c}\text { Relatively as } \\
\text { expected }\end{array}$ & $\begin{array}{c}\text { Relatively as } \\
\text { expected }\end{array}$ & $\begin{array}{c}\text { Relatively as } \\
\text { expected }\end{array}$ & Expected \\
\hline 9 & Expected & Expected & Expected & Expected & $\begin{array}{c}\text { Below the } \\
\text { expected }\end{array}$ \\
\hline 10 & Exceptional & Exceptional & Exceptional & Exceptional & $\begin{array}{c}\text { Extremely } \\
\text { favorable }\end{array}$ \\
\hline
\end{tabular}

Costumers were surveyed immediately after using the products and services, while their memories and impressions were fresh.

\section{Collecting data on the structure of management and employees}

Collecting data on the structure of management and employees was conducted through interviews with the management and employees in the analysed hospitality facilities, collecting data on the number, age and qualifications of employees. 
Calculation of index of qualification structure used the following scoring system:

- the greatest value of 10 is given to faculty graduates,

- 9 points to college graduates,

- 8 points to staff that completed one-year specialisation after high School,

- 7 points to high school graduates,

- 6 to three-year secondary school graduates and

- 5 to unqualified staff (Krasavčić, 2012).

\section{Statistical data processing}

Data analysis was performed using the statistical software Statistics 10 and Eviews 3.1. Basic characteristics of the observed variables (phenomena) in both research phases were calculated using indicators of descriptive statistics (Stojković, 2008): mean, extreme values (minimum and maximum), standard deviation and coefficient of variation.

Regression and correlation analysis is performed below to determine the level and form of influence and dependence between the structure of employees on the studied parameters of guest satisfaction using the method of regression analysis, which ensures accurate and valid results, which, in this paper, was done by applying:

- simple linear regression and

- multiple linear regression.

In order to achieve the aim of research to examine the impact of the structure of human resources on guest satisfaction with the quality of products and services, regression analysis was performed. The first phase of implementation of this method defined variables to be taken into account in the assessment of adequate regression models.

As an indicator of guest satisfaction, which in a regression analysis is a dependent variable (Y), it was observed an average score of quality of products and services, which in its value contains information on all five properties that make the evaluated quality, namely: ambience, atmosphere, and quality of service, quality of food, drinks and prices.

The influence of the structure of employees as a factor is an independent variable (X), which is observed on the basis of:

- index of the qualification structure $\left(X_{P}\right)$;

- age of workers $\left(X_{2}\right)$;

- other workers $\left(X_{3}\right)$;

- assistant workers $\left(X_{4}\right)$;

- sensory quality of food $\left(X_{5}\right)$;

- quality of other services $\left(X_{6}\right)$; 
- ambience $\left(X_{7}\right)$;

- inner atmosphere $\left(X_{8}\right)$;

- quality of service $\left(X_{q}\right)$;

- quality of food and beverages $\left(\mathrm{X}_{10}\right)$ and

- prices $\left(X_{11}\right)$.

In applying the multiple regressions, the focus is on the proper choice of model and the proper interpretation of the results.

Starting from the analysed phenomena in the work, appropriate models are selected that reflect the influence of the structure of employees on guest satisfaction with the quality of restaurant food and service.

The application of the method of regression analysis in research is followed by certain problems such as problems in the selection of variables, problems of assessment of parameters, autocorrelation, multicollinearity, and others which was taken into account in the analysis wherein some of the problems are eliminated in order to obtain more accurate and valid results.

The phase of checking the adequacy of the selected model means checking fulfilment of model assumptions which uses different tests. The paper for each selected model tested the significance using the method of analysis of variance, that is, by performing $\mathrm{F}$ - test.

\section{Results and discussion}

\section{Analysis of guest satisfaction with quality of restaurant products and services}

Based on the overall mean of evaluations of all quality indicators in Table 2 it can be concluded that guest satisfaction is at a slightly lower level than expected one ( $\bar{X}$ $=7.23$ ) and the coefficient of variation is $22.45 \%$.

Table 2. Basic indicators of consumer satisfaction with the quality of products and services

\begin{tabular}{|l|c|c|c|c|c|}
\hline \multirow{2}{*}{\multicolumn{1}{|c|}{ Indicators }} & \multirow{2}{*}{$\begin{array}{c}\text { Average } \\
\text { value } \\
(\overline{\mathrm{X}})\end{array}$} & \multicolumn{2}{|c|}{ Variation interval } & \multirow{2}{*}{$\begin{array}{c}\text { Standard deviation } \\
(\sigma)\end{array}$} & $\begin{array}{c}\text { Coefficient } \\
\text { of variation } \\
(\mathrm{V} \%)\end{array}$ \\
\cline { 3 - 4 } & 7.83 & 4.00 & 10.00 & 1.72 & 22.01 \\
\hline Ambience & 7,70 & 4.00 & 10.00 & 1.74 & 22.66 \\
\hline Atmosphere & 7,57 & 5.00 & 10,00 & 1.52 & 20.14 \\
\hline Service quality & 7.30 & 5.00 & 10.00 & 1.42 & 19.42 \\
\hline $\begin{array}{l}\text { Food and } \\
\text { beverage quality }\end{array}$ & 6.27 & 3.00 & 9,00 & 1.84 & 29.31 \\
\hline Prices & $\mathbf{7 . 2 3}$ & $\mathbf{3 . 1 0}$ & $\mathbf{9 . 4 0}$ & $\mathbf{1 . 6 2}$ & $\mathbf{2 2 . 4 5}$ \\
\hline Total mark & &
\end{tabular}

Guests are most satisfied with the ambience $(\bar{X}=7.83 ; V=22.01 \%)$ and inner atmosphere $(\bar{X}=7.70 ; V=22.66 \%)$. The lowest average score the guests assigned to prices $(\bar{X}=6.27 ; V=29.31 \%$ ), thus it can be considered that they are least satisfied with 
this element, or that the prices are slightly higher than expected. This price estimation by guests caused the overall evaluation of the quality of the restaurants $(\bar{X}=7.23)$ to be lower than expected.

\section{Analysis of the structure of management and employees in the restaurant industry}

The average age of employees in the facilities is 34 years, and varies in the range from 25 , the minimal recorded age, up to a maximum recorded age, which is 45 years, which confirms the coefficient of variation of $16.89 \%$ (Table 3 ).

Table 3. Structure of management and other employees

\begin{tabular}{|c|c|c|c|c|c|}
\hline \multirow{2}{*}{ INDICATORS } & \multirow{2}{*}{$\begin{array}{l}\text { AVERAGE } \\
\text { VALUE ( } \\
\overline{\mathrm{X}})\end{array}$} & \multicolumn{2}{|c|}{\begin{tabular}{|l} 
VARIATION \\
INTERVAL
\end{tabular}} & \multirow{2}{*}{$\begin{array}{l}\text { STANDARD } \\
\operatorname{DEVIATION}(\sigma)\end{array}$} & \multirow{2}{*}{$\begin{array}{l}\text { COEFFICIENT } \\
\text { OF VARIATION } \\
(\mathrm{V} \%) \\
\end{array}$} \\
\hline & & Minimum & Maximum & & \\
\hline $\begin{array}{l}\text { Total number of } \\
\text { workers }\end{array}$ & 16.00 & 5.00 & 26.00 & 5.16 & 32.01 \\
\hline Age of workers & 33.73 & 25.00 & 45.00 & 5.70 & 16.89 \\
\hline $\begin{array}{l}\text { Number of } \\
\text { assisting workers }\end{array}$ & 3.00 & 0.00 & 18.00 & 3.61 & 121.53 \\
\hline $\begin{array}{l}\text { Number of other } \\
\text { workers }\end{array}$ & 2.00 & 0.00 & 11.00 & 3.17 & 141.93 \\
\hline $\begin{array}{l}\text { Index of skills } \\
\text { structure }\end{array}$ & 6.68 & 5.60 & 8.55 & 0.72 & 10.79 \\
\hline
\end{tabular}

Not all the restaurants have auxiliary and support staff. There are restaurants that do not have any, and those with up to 18 auxiliary and 11 other workers. Thirteen of the thirty facilities employ other workers, and twenty of them have auxiliary workers. The average number of other employees, where available, is two and the maximum number is eleven (restaurant no. 14). Facilities employ on average three auxiliary workers, and most of them are employed in the facility no. 22, that is, eighteen of them. The coefficient of variation for auxiliary workers is $121.53 \%$, and for other workers is even higher $(141.93 \%)$, which indicates that there are restaurants that employ a large number of semi-skilled and unskilled labour and that there are huge differences among them.

\section{Analysis of the index of employee qualification structure}

Positions in the observed objects are structured as follows: restaurant manager, banquet manager, kitchen manager, chef and waiter. Within the defined positions, facilities employ a various number of workers of various qualifications. Starting from this diversity both in number and in qualifications of employees, in order to compare the observed facilities, we calculated values of the qualification structure, which takes into account the observed differences.

Managers are the basis and prerequisite of a successful operation of modern enterprises (Emenheiser, Clay, Palakurthi, 1998) therefore in determining the index of qualification structure as a good indicator of the state of the structure of employees the highest score 
is assigned to employees who have the highest level of education. As a rule, these are the managers regardless of which operating managerial positions they hold.

Figure 1. Trends in values of the index of the qualification structure in the restaurant industry in Belgrade (10 - Faculty graduates, 9 - college graduates, 8 - completed one-year specialization after high school, 7 - high school graduates, 6 - three-year secondary school graduates and 5 - unqualified)

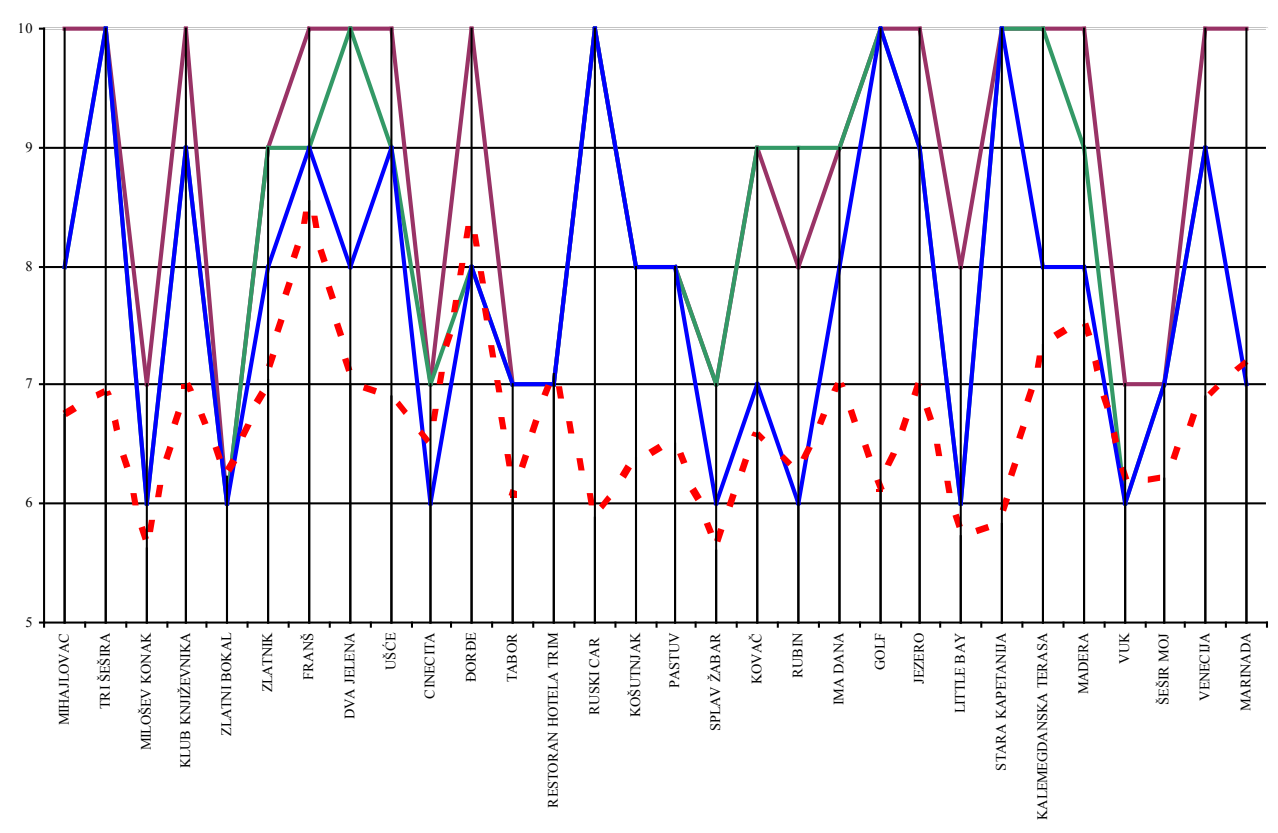

The highest number of restaurants have the qualification structure index between 6 and 7 while restaurants 14, 24, 23, 3 and 17 have the lowest qualification structure and the qualification structure index is less than 6; Restaurants, 4, 6, 7, 8, 13, 25 and 26 have a high index of qualification structure (over 7), indicating that their management and other professional workers have the highest qualifications.

The restaurant no. 7 has the largest index on the basis of the qualification structure of employees with an average score of 8.55. This restaurant employs ten workers, one of whom with a university degree as a manager of the restaurant. Banquet manager has collage degree or sixth level of qualifications, as is the case with the kitchen manager, while the remaining employees have a one-year specialization after high school.

Slightly lower index with an average score of 8.40 has the restaurant no. 11. This restaurant employs eleven employees, of which one with a university degree as a manager 
of the restaurant. Banquet managers and kitchen manager are workers with a one-year specialization completed after high school, while the rest, i.e. cooks and waiters, also have secondary education including five workers with completed specialization.

The lowest index of employee qualification structure of 5.60 has the restaurant no. 17 with twenty employees. The restaurant manager is a four-year high school graduate, which is the case with the banquet manager, while the kitchen manager has completed tree-year high school.

\section{Analysis of the impact of the structure of employees on guest satisfaction}

Analysis of total qualification structure index of employees within hospitality facilities and guest satisfaction showed some deviation in the restaurants no. 15, 16 and 24, where guest satisfaction is below the average for the qualification structure of employees (Figure 2).

Figure 2. Relationship between qualification structure and guest satisfaction

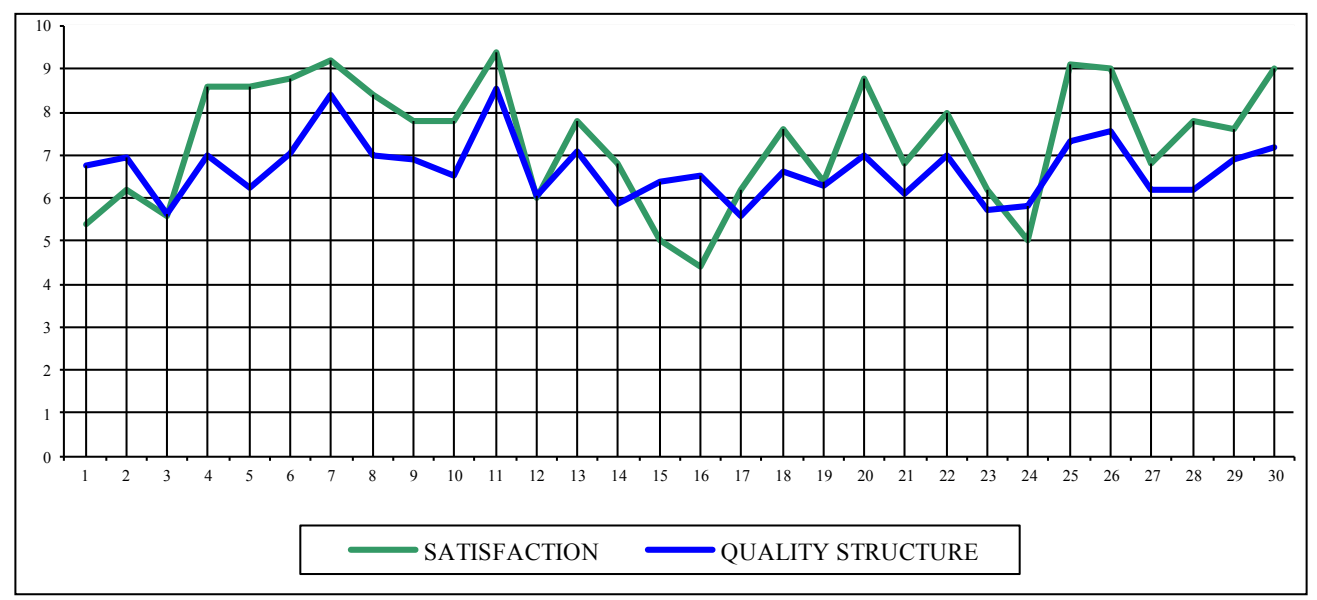

\section{Analysis of dependence of guest satisfaction on individual quality factors}

The dependence of satisfaction of observed factors is viewed on the basis of the values of simple correlation coefficients, which are expanded with the parameters that relate to the sensory quality of food and the quality of other services provided by hospitality facilities (Table 4).

Sensory quality is processed based on parameters that are related to aroma, juiciness, tenderness, taste and remainder in chewing of selected dishes. The average score for quality of food is 5.23 , which indicates that the evaluated food at Belgrade restaurants has a moderate quality. The minimum score for food quality has two facilities and it is 3.2 (moderately poor). The maximum score for quality of food as a whole on the basis of five properties was 6.6 (very high quality). 
The mean of the total number of positive responses about other services that are related to the availability of bartender, waiter for flambé, implemented HACCP, wine offer and foreign language skills of employees are 5.33 and are characterized by moderate variability, which expressed by the coefficient of variation is around $21 \%$. The values of simple correlation coefficients in Table 5 show that the level of guest satisfaction is significantly affected by the majority of observed factors.

Table 4. Additional parameters: analysis of sensory quality of food and other services

\begin{tabular}{|c|c|c|c|c|c|}
\hline \multirow{2}{*}{ INDICATORS } & \multirow{2}{*}{$\begin{array}{l}\text { AVERAGE } \\
\text { VALUE ( } \\
\bar{X})\end{array}$} & \multicolumn{2}{|c|}{$\begin{array}{l}\text { VARIATION } \\
\text { INTERVAL } \\
\end{array}$} & \multirow{2}{*}{$\begin{array}{c}\text { STANDARD } \\
\text { DEVIATION }(\sigma)\end{array}$} & \multirow{2}{*}{$\begin{array}{c}\text { COEFFICIENT } \\
\text { OF VARIATION } \\
\text { (V \%) }\end{array}$} \\
\hline & & Minimum & Maximum & & \\
\hline $\begin{array}{l}\text { Sensory quality } \\
\text { of food }\end{array}$ & 5.23 & 3.20 & 6.60 & 0.99 & 19.01 \\
\hline Other services & 5.33 & 4.00 & 7.00 & 1.12 & 21.08 \\
\hline
\end{tabular}

The greatest impact is shown by ambience and quality of service $(r=0.85)$ followed by the inner atmosphere $(r=0.78)$, quality of food and beverages $(r=0.76)$, the average score of sensory quality of food and price $(\mathrm{r}=0.72)$, the index of the qualification structure $(r=0.71)$ and with the lowest impact is workers age $(r=0.37)$. It is worth noting that the price largely depends on the type of restaurant (Berardi et al., 2014).

Although all of these variables significantly influence the satisfaction, due to high dependence between some of them, in order to avoid the presence of multicollinearity in models and thus bringing into question the validity of the obtained evaluation parameters, these variables are not included together in a model. On the other hand, to investigate and quantify their impact on satisfaction several models are rated. The matrix of correlation coefficients of the set of variables is given in Table 5.

The influence of the structure of managers and employees on guest satisfaction is reviewed based on the following model (M1):

$$
\hat{\mathrm{Y}}=-5.354++1.504 \mathrm{X}_{1} 0.075 \mathrm{X}_{2}
$$

As factors that significantly affect the guest satisfaction, this model included the qualification structure index and the average age of workers. Both included factors have a positive impact, that is, they both increase the level of guest satisfaction. The values show that when these elements of management are in question, the greater relative impact on the level of satisfaction has the expertise of managers and staff expressed by the qualification structure index level and the impact based on the value of the standardized coefficient of regression is about $67 \%$. The relative influence of the average age of workers on guest satisfaction, based on the same indicator is $26.5 \%$.

The estimated model as a whole shows statistical significance ( $\mathrm{F}=17.99)$, as well as both, included independent variables $\left(\mathrm{t}_{1}=5.23, \mathrm{t}_{2}=2.07\right)$, thus the model is considered as appropriate for the analysis of the impact of the management structure and staff 
on the guest satisfaction. Also based on this model it is concluded that the level of satisfaction of $54 \%$ is explained by the influence of index of qualification structure of employees and the average age of employees.

Table 5. Matrix of correlation coefficients of set of variables

\begin{tabular}{|c|c|c|c|c|c|c|c|c|c|c|c|c|}
\hline Variables & $Y_{1}$ & $X_{1}$ & $X_{2}$ & $X_{3}$ & $X_{4}$ & $X_{5}$ & $X_{6}$ & $X_{7}$ & $X_{8}$ & $X_{9}$ & $X_{10}$ & $X_{11}$ \\
\hline$Y$ & 1.00 & $0.71^{* *}$ & $0.37^{\prime \prime}$ & -0.17 & 0.01 & $0.72^{*}$ & 0.35 & $0.85^{\prime \prime \prime}$ & $0.78^{*}$ & $0.85^{\prime \prime}$ & $0.76^{*}$ & $0.72^{* *}$ \\
\hline$X_{1}$ & & 1.00 & 0.16 & -0.24 & -0.08 & $0.74^{*}$ & $0.43^{* *}$ & $0.59^{* *}$ & $0.50^{\circ *}$ & $0.64^{* *}$ & $0.71^{* \prime}$ & $0.54^{* *}$ \\
\hline$X_{2}$ & & & 1.00 & -0.24 & 0.25 & 0.19 & -0.02 & 0.21 & 0.15 & 0.32 & 0.24 & $0.37^{* *}$ \\
\hline$X_{3}$ & & & & 1.00 & $0.56^{\prime \prime}$ & 0.01 & 0.05 & -0.19 & -0.22 & -0.26 & -0.05 & -0.06 \\
\hline$X_{1}$ & & & & & 1.00 & 0.02 & -0.08 & -0.15 & -0.16 & -0.02 & 0.19 & 0.12 \\
\hline$X_{5}$ & & & & & & 1.00 & $0.39^{* *}$ & $0.66^{* *}$ & $0.56^{*}$ & $0.71^{* \prime}$ & $0.69^{* *}$ & $0.57^{* *}$ \\
\hline$X_{6}$ & & & & & & & 1.00 & $0.40^{* *+}$ & 0.32 & 0.33 & 0.30 & $0.42^{* *}$ \\
\hline$X_{7}$ & & & & & & & & 1.00 & $0.83^{* *}$ & $0.68^{* \prime}$ & $0.56^{* *}$ & $0.62^{* *}$ \\
\hline$X_{8}$ & & & & & & & & & 1.00 & $0.71^{\prime \prime}$ & $0.54^{* \prime}$ & $0.49^{*}$ \\
\hline$X_{0}$ & & & & & & & & & & 1.00 & $0.76^{* *}$ & $0.66^{* \prime}$ \\
\hline$X_{10}$ & & & & & & & & & & & 1.00 & $0.63^{* *}$ \\
\hline$X_{11}$ & & & & & & & & & & & & 1.00 \\
\hline
\end{tabular}

If we look at the elements that make the guest satisfaction with quality, namely: ambience, inner atmosphere, quality of service, quality of food and drinks and prices, they all show a significant impact on satisfaction. However, there is also a statistical relationship between the elements themselves, and they cannot be included in the model together. The element that shows the greatest impact on satisfaction is the quality of service $(r=0.66)$ and based on that the following model is estimated $\left(M_{2}\right)$ :

$$
\hat{\mathrm{Y}}=0.344+0.910 \mathrm{X}_{9}
$$

This model shows that the improvement of the quality of services brings an increase in the level of guest satisfaction. In addition of showing that the model as a whole is statistically significant, the values in Table 6 show that the explanation of the change in the level of satisfaction, influenced by an increase in quality of services is $72 \%$.

The positive influence of qualification structure of managers and elements of satisfaction on increase in satisfaction is demonstrated by the previously estimated models in which the impact of these factors is observed independently of each other. In order to evaluate their synergetic effects on the satisfaction, we also estimated models in which these two groups of factors are included together.

Starting from the fact that the matrix of simple correlation coefficients shows that the greatest impact on satisfaction has the index of qualification structure of employees and the quality of service, firstly we estimated the model (M3) which includes these two variables: 


$$
\hat{\mathrm{Y}}=-2.403+0.625 \mathrm{X}_{1}+0.722 \mathrm{X}_{9}
$$

Assessment of this model significantly increased explanation of the change in satisfaction and reduced error of the model of estimated parameters, which together gives more valid results using this model for prognostic purposes. Applying automatic selection of variables by exclusion from the beginning the following regression model (M4) is estimated to examine the impact of management and elements of satisfaction on its change:

$$
\hat{\mathrm{Y}}=-3.846+0.690 \mathrm{X}_{1}+0.055 \mathrm{X}_{2}+0.590 \mathrm{X}_{7}
$$

This model included the tree of the starting eleven independent variables. Selected variables have statistically significant, positive impact on the level of customer satisfaction.

The values of standardized regression coefficients show that when observing this set of variables, the greatest relative impact on satisfaction has the ambience with $63 \%$, the index of qualification structure with $31 \%$, and the average age of workers with $19 \%$. The overall explanation of the change in satisfaction by this set of variables is $80 \%\left(\bar{R}^{2}=0,799\right)$. In order to compare all of the estimated models in the analysis of customer satisfaction, depending on the observed factors, their verification has been made based on statistical tests of the first order (Table 6).

Table 6. Estimates of model for examination of customer satisfaction based on statistical criteria

\begin{tabular}{|c|c|c|c|c|}
\hline \multirow{2}{*}{ Models } & \multicolumn{4}{|c|}{ First row tests } \\
\cline { 2 - 5 } & \multirow{2}{*}{ F-distribution } & $\mathbf{R}^{2}$ & $\bar{R}^{2}$ & $\mathbf{S}_{\mathbf{e}}$ \\
\hline M1 & $17.99^{* *}$ & 0.57 & 0.54 & 1.10 \\
\hline M2 & $75.80^{* *}$ & 0.73 & 0.72 & 0.86 \\
\hline M3 & $46.74^{* *}$ & 0.78 & 0.76 & 0.80 \\
\hline M4 & $39.45^{* *}$ & 0.82 & 0.80 & 0.73 \\
\hline
\end{tabular}

The table shows that all the estimated models are statistically significant (F-relationship). The greatest explanation of satisfaction is given by the model M4 as it has the highest value of the coefficient of determination $\left(\mathrm{R}^{2}\right)$ and adjusted coefficient of determination $\left(\bar{R}^{2}\right)$.

\section{Conclusion}

Based on research and statistical analysis of data using appropriate models it was concluded that guest satisfaction with overall quality of restaurant products and services is at a low level. Guests are most satisfied with ambience and inner atmosphere and least satisfied with prices.

Based on the results it was concluded that restaurants employ a large number of semiqualified and unqualified labour and there are huge differences between them. This has led to that the most of the facilities have a low index of qualification structure, which is the case with management as well. 
The statistical survey of the influence of the structure of management and staff on guest satisfaction with the quality of hospitality services confirmed a significant influence. According to the obtained values, the greatest impact on satisfaction has the ambience and quality of services, followed by an inner atmosphere, quality of food and drinks and the average score of dishes and prices.

Applying adequate regression models led to the conclusion that the qualification structure index and the average age of workers have a significant impact on guest satisfaction, with the greatest impact on the quality of services and the ambience. Here the question is what elements of the ambience are crucial. Among the important elements of the ambience Gaurav and Kartik (2012) state colours and lighting, which should be further explored.

When one takes into account the heterogeneity of services in the restaurant industry and personal dimension of their implementation, it is extremely difficult to achieve full satisfaction of consumers. The task of management is to organize the business by creating a positive relationship between all levels of the organization hierarchy, which will be transferred to the customer as she/he will be welcomed, comfortably housed, well served, hosted, and in the end pleasantly accompanied from the hospitality facility (Baraban, Durocher, 2001).

\section{Acknowledgements}

The work is part of the research projects III- 46005 and III- 46009 funded by the Ministry of Science and Technological Development of Republic of Serbia.

\section{Conflict of interests}

The authors declare no conflict of interest.

\section{References}

1. Andaleeb, S.S., \& Conway, C. (2006). Customer satisfaction in the restaurant industry: an examination of the transaction-specific model. Journal of Services Marketing, 20(1), 3-11. DOI: 10.1108/08876040610646536

2. Baker, J, Parasuraman, A., Grewal, D., \& Voss, G. (2002). The influence of multiple store environment cues on perceived merchandise value and patronage intentions. Journal of Marketing, 66(2), 120. DOI: 10.1509/ jmkg.66.2.120.18470

3. Baraban, R. S., \& Durocher, J. F. (2001). Successful restaurant design (2nd ed). Wiley, New York.

4. Baum, T., \& Nickson, D. (1998). Teaching human resource management in hospitality and tourism: a critique. International Journal of Contemporary Hospitality Management, 10(2), 75-79. DOI: 10.1108/09596119810207228 
5. Berardi, N., Eife, T., \& Gautier, E. (2014). Optimal price setting during a currency changeover: theory and evidence from french restaurants. Applied Economics, 46(23), 2766-2782. DOI: 10.1080/00036846.2014.914144

6. Blešic I., Tešanovic D., \& Psodorov Đ. (2011). Consumer Satisfaction and Quality Management in the Hospitality Industry in South-East Europe. African Journal of Business Management, 5(4), 1388-1396. DOI: 10.5897/AJBM10.1299

7. Bolton, R.N., \& Drew, J.H. (1991). A multistage model of customers' assessments of service quality and value. Journal of Consumer Research, 17, 375-384. DOI: 10.1086/208564

8. Brooks, R. (2000) Why loyal employees and customers improve the bottom line. Journal of Quality and Participation, 23(2), 40-44.

9. Caruana, A., Money, A.H., \& Berthon, P.R. (2000). Service quality and satisfaction - the moderating role of value. European Journal of Marketing, 34(11/12), 1338-1353. DOI: 10.1108/03090560010764432

10. Chebat, J.C, Morrin, M., \& Chebat, D.R. (2009). Does age attenuate the impact of pleasant ambient scent on consumer response? Environment and Behavior, 41(2), 258-267. DOI: 10.1177/0013916507311792

11. Connolly, P., \& McGing, G. (2006). Graduate education and hospitality management in Ireland. International Journal of Contemporary Hospitality Management, 18(1), 50-59. DOI: 10.1108/09596110610641975

12. Durrani, A., \& Rajagopal, L. (2016). Restaurant human resource managers' attitudes towards workplace diversity, perceptions and definition of ethical hiring. International Journal of Hospitality Management Volume, 53, 145-151. DOI: $10.1016 /$ j.ijhm.2015.10.009

13. Emenheiser, D.A., Clay, J. M. \& Palakurthi, R. (1998). Profiles of successful restaurant managers for recruitment and selection in the US. International Journal of Contemporary Hospitality Management, 10(2), 54 - 62. DOI: 10.1108/09596119810207192

14. Fick, G. R., \& Ritchie, J. R. (1991). Measuring Service Quality in the Travel and Tourism Industry. Journal of Travel Research, 30(2), 2-9. DOI: 10.1177/004728759103000201

15. Gagic, S. Jovičić, A., Tešanović, D., \& Kalenjuk, B. (2014). Motives for food choice among Serbian consumers. Economics of Agriculture, 61(1), 41-51. DOI: $10.5937 /$ ekoPolj1401041G

16. Gaurav, T., \& Kartik, D. (2012). Exploration of service quality factors in the restaurant industry: a study of selected restaurants in new delhi region. Journal of Services Research, 14(1), 8-26.

17. Gueguen, N., \& Petr, C. (2006). Odors and consumer behaviour in a restaurant. International Journal of Hospitality Management, 25, 335-339. DOI: $10.1016 / \mathrm{j} . \mathrm{ijhm} .2005 .04 .007$ 
18. Han, H., \& Ryu, K. (2009). The Roles of the Physical Environment, Price Perception, and Customer Satisfaction in Determining Customer Loyalty in the Restaurant Industry. Journal of Hospitality \& Tourism Research, 33(4), 487-510. DOI: 10.1177/1096348009344212

19. Heide, M. \& Gronhaug, K. (2009). Key factors in guests' perception of a hotel atmosphere. Cornell Hotel and Restaurant Administration Quarterly, 50(1), 29-43. DOI: 10.1177/1938965508328420

20. Kim, W.G., Ng, C.Y.N., \& Kim, Y.S. (2009). Influence of institutional DINESERV on consumersatisfaction, return intentions, and word-of-mouth. International Journal of Hospitality Management, 28(1), 10-17. DOI: 10.1016/j.ijhm.2008.03.005

21. Kim, Y.S., Moreo, P.J., \& Yeh, R.J.M. (2004). Customers' satisfaction factors regarding university food court service. Journal of Foodservice Business Research, 7, 97-110. DOI: 0.1300/J369v07n04_05

22. Knuston, B., Stevens, P., Patton, M., \& Thompson, C. (1992). Consumers Expectations for Service Quality in Economy, Mid-Price and Luxury Hotels. Journal of Hospitality \& Leisure Marketing, 1(2), 27-43. DOI: 10.1300/ J150v01n02_03

23. Krasavčić, M. (2012). The impact on the quality of management services. Doctoral Dissertation, Faculty of science, Department of geography, tourism and hotel management, Novi Sad.

24. Liu, Y., \& Jang, S. (2009). The effects of dining atmospherics: An extended Mehrabian-Russell model. International Journal of Hospitality Management, 28(4), 494-503. DOI: 10.1016/j.ijhm.2009.01.002

25. Luo, X., \& Homburg, C. (2007). Neglected Outcomes of Customer Satisfaction. Journal of Marketing, 71(2), 133-149. DOI: 10.1509/jmkg.71.2.133

26. Marinković, V., Senić, V., \& Dimitrovski, D. (2013). Measuring consumers' attitudes towards service quality in restaurants. Teme, 37, 319-338.

27. Martíneztur, V., Tordera, N., Peiró, J., \& Potocnik, K. (2011). Linking Service Climate and Disconfirmation of Expectations as Predictors of Customer Satisfaction: A mCross-Level Study 1. Journal of Applied Social Psychology, 41(5), 1189-1213. DOI: 10.1111/j.1559-1816.2011.00753.x

28. Namkung, Y., \& Jang, S. (2007). Does food quality really matter in restaurants? It's impact on consumersatisfaction and behavioural intentions. Journal of Hospitality and Tourism Research, 31(3), 387-409. DOI: 10.1177/1096348007299924

29. Pološki Vokic, N., \& Grizelj, H. (2007). Training and development in Croatian organizations. Economic Review, 58(12), 851-880.

30. Seth, N., Deshmukh, S.G., \& Vrat, P. (2005). Service quality models: a review. International Journal of Quality \& Reliability Management, 22(9), 913-949. 
31. Soriano, D. (2002). Customers' expectations factors in restaurants: The situation in Spain. International Journal of Quality \& Reliability Management, 19(8/9), $1055-1067$.

32. Stevens, P., Knutson, B., \& Patton, M. (1995). DINESERV: a tool for measuring service quality in restaurants. Cornell Hotel and Restaurant Administration Quarterly, 36, 56-60. DOI: 10.1177/001088049503600226

33. Stewart, T. A. (2001). The Wealth of Knowledge - Intellectual Capital and the Twenty-First Century Organization, Nicholas Brealey Publishing, London.

34. Stojković, M. (2008). Statistical methods in tourism. Faculty of Sciences, Department of Geography, Tourism and Hotel Management, University of Novi Sad, Novi Sad.

35. Suh, E., West, J., \& Shin, J. (2012). Important competency requirements for managers in the hospitality industry. Journal of Hospitality, Leisure, Sport \& Tourism Education, 11(2), 101-112. DOI: 10.1016/j.jhlste.2012.02.005

36. Sulek, J.M., \& Hensley, R.L. (2004). The Relative Importance of Food, Atmosphere, and Fairness of Wait: The Case of a Full-service Restaurant. Cornell Hotel and Restaurant Administration Quarterly, 45(3), 235-247. DOI: 10.1177/0010880404265345

37. Sureshchandar, G.S., Rajendran, C., \& Anantharaman, R.N. (2002). The relationship between service quality and customer satisfaction - a factor specific approach. Journal of Services Marketing, 16(4), 363-379. DOI: 10.1108/08876040210433248

38. Syed, H., Muhammad, S., \& Abdul, R. (2011). Relationship between Various Employee Performance Recognition Techniques and Customer Satisfaction: Evidence from the Restaurant Industry of Pakistan. European Journal of Social Science, 26(3), 318-322.

39. Šapić, S., Furtula, S., \& Durkalić, D. (2018). Prestige and national identity as predictors of food products purchase. Economic of Agriculture, 65(2), 643-657.

40. Tešanović, D., Krasavčić, M., Kalenjuk, B., Portić, M., \& Gagić, S. (2014). The influence of the structure of employees on sensory quality of restaurants food. British Food Journal, 116(3), 527 - 543. DOI: 10.1108/BFJ-05-20120112

41. Wang, X. (2011). The Effect of Unrelated Supporting Service Quality on Consumer Delight, Satisfaction, and Repurchase Intentions. Journal of Service Research, 14(2), 149-163. DOI: 10.1177/1094670511400722

42. Weiss, R., Feinstein, A.H., \& Dalbor, M. (2005). Customer satisfaction of theme restaurant attributes and their influence on return intent. Journal of Foodservice Business Research, 7(1), 23-41. DOI: 10.1300/J369v07n01_03 
43. Xia, L., Monroe, K.B., \& Cox, J.L. (2004). The price is unfair! A conceptual framework of price fairness perceptions. Journal of Marketing, 68, 1-15. DOI: 10.1509/jmkg.68.4.1.42733

44. Yuksel, A., \& Yuksel, F. (2002). Measurement of tourist satisfaction with restaurant services: a segment-based approach. Journal of Vacation Marketing, 9(1), 52-68. DOI: 10.1177/135676670200900104

45. Zemke, D. V., \& Shoemaker, S. (2007). Scent across a crowded room: Exploring the effect of ambient scent on social interactions. International Journal of Hospitality Management, 26(4), 927-940. DOI: 10.1016/j.ijhm.2006.10.009

46. Zemke, D.V., \& Shoemaker, S. (2008). A sociable atmosphere: ambient scent's effect on social interaction. Cornell Hospitality Quarterly, 49(3), 317-329. DOI: $10.1177 / 1938965508320626$ 